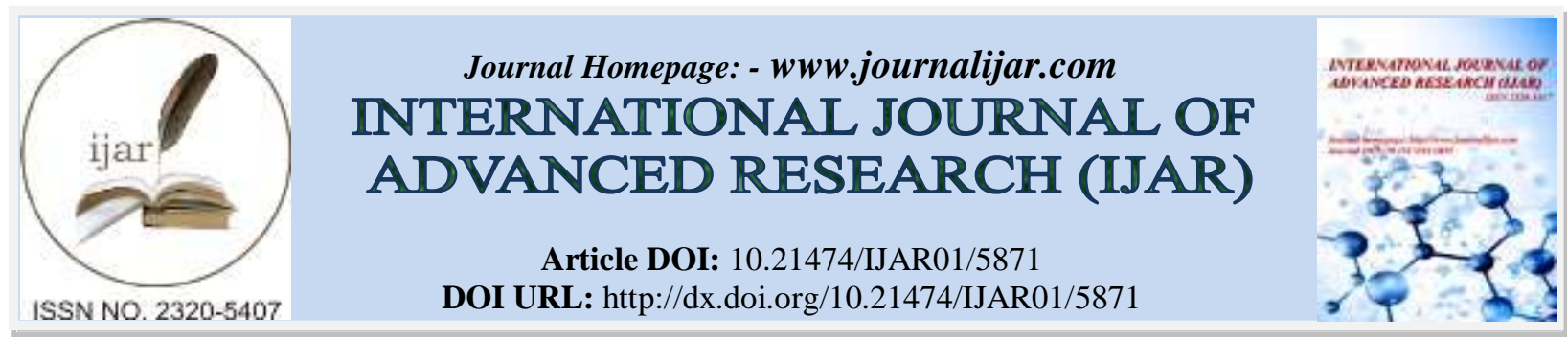

RESEARCH ARTICLE

\title{
THE EFFECT OF HYPNO-EFT THERAPY ON THE BLOOD PRESSURE IN HYPERTENSIVE PATIENTS AT THE DEPARTMENT OF HEALTH TASIKMALAYA REGION.
}

\author{
Betty suprapti ${ }^{1}$ and yanyan bahctiah ${ }^{2}$. \\ 1. Health Polytechnic of Ministry of Health Tasikmalaya. \\ 2. Cilolohan Street No.35, Kahuripan, Tawang, Tasikmalaya, West Java 46115.
}

\section{Manuscript Info}

Manuscript History

Received: 15 September 2017

Final Accepted: 17 October 2017

Published: November 2017

Key words:-

Hypno-EFT, hypertension, blood pressure, anxiety.

\begin{abstract}
This research aims to determine the effect of Hypno-EFT therapy on blood pressure in hypertensive patients at the Department of Health Tasikmalaya Region. Researchers conducted the study of advanced research hypertension management by using Hypno-EFT therapy. Hypno-EFT is expected to be stronger in controlling hypertension trigger either physically or biology factors. The design of the study used quasi-experimental with non-randomized pretest-posttest group design. The intervention group besides giving pharmacological drug therapy also given Hypno-EFT therapy three times. While the control group did not give Hypno-EFT therapy, but still given pharmacological drug therapy for hypertension and hypertension management explanations. Samples of this study was 52 respondents which chosen by convenient sample technic. The data analysis used $t$-test and paired-t data analysis. The results showed that the Hypno-EFT therapy have significant effect to lowering blood pressure, both systolic $(\rho=0,019)$ and diastolic $(\rho=0,001)$. Hypno-EFT can reduce pain perception, resolve coping ability and quality of life, have a direct effect on specific phobias, anxiety and depression, the psychological trauma and coronary heart disease and hypertension. This research is expected to be useful as a reference in the management of hypertensive patients, especially to control stress or anxiety.
\end{abstract}

Copy Right, IJAR, 2017,. All rights reserved.

\section{Introduction:-}

Hypertension is still reputed as trigger disease for further serious and deadly disease. Hypertension is often referred as a silent killer disease, because the disease has no specific symptoms that are recognized by the sufferer.

Hypertension continues to increase years to years. As many as 1 billion people in the world or 1 of 4 adults is suffer hypertension. It is estimated that the number of people with hypertension will increase to 1.6 billion by 2025 (Ramadan, 2010; Santoso, 2010).

The incidence of hypertension in Indonesia based on Riskesdas data in 2013 about 25.8 percent, men 22.8 percent and women 28.8 percent (Susilawati, 2015). 
While in Tasikmalaya City found the increasing incidence of new hypertension case is high enough. In 2010 the number of hypertension was 25,825 people, and in 2015 was 35,601 people. There has been an increase of 9,776 cases over the last 5 years. Based on data of annual report from Public Health Center (Puskesmas) at the Department of Health Tasikmalaya Region 2015, hypertension patient occupied ranks 2 of 10 most diseases with number of patient 35.601 people (Report of Department of Health Tasikmalaya City, 2015).

Hypertension can occur by various trigger, both physically, biologically, psychologically and socially. Management of hypertension is not to treat hypertension but to control blood pressure in normal range.

Non-pharmacology therapy such as Hypno-EFT is still not widely applied in Puskesmas, as well as in Puskesmas that located in Department of Health Tasikmalaya Region. Researchers conducted research on hypertensive patients who went to Puskesmas. The patients given intervention by using Hypno-EFT therapy as non-pharmacology therapy for three times with one-day interval.

Based on preliminary study conducted by the researchers in December 2015 through interview with nurse who hold perkesmas program in Puskesmas Kahuripan, nurse said until 2015 cases of hypertension continue to grow and until the end of year 2015 recorded 1.913 cases. The management of hypertension is dominated by pharmacological therapy, but not all of these pharmacological therapies achieve the desired results. The patient's blood pressure remains high despite long-term therapy with anti-hypertensive drugs. This phenomenon provides an illustration that the management of hypertension in Puskesmas is still not optimal.

\section{Method :-}

The design of this research used quasi experiment with non-randomized pretest-posttest group design. The population this research where all people who suffered hypertension at Department of Health Tasikmalaya Region. The population of this research was 35.601 people. Total sample of this research was 52 respondents. This respondent devided into two group which is 26 people for intervention group and 26 people for control group.

In this design, both the intervention group and the control group were involved in the research. The difference is the intervention group aside from given pharmacological drug therapy also given Hypno-EFT therapy for three times. While the control group did not give Hypno-EFT treatment, but still given pharmacological drug therapy and explanation of hypertension management. Data analysis to know the difference of blood pressure level before and after intervention was done by paired t-test (Dahlan, 2009). If the paired t-test produces significance value of $p$ $<0.05$ then it can be concluded that there is a significant difference in mean blood pressure between before and after Hypno-EFT therapy.

\section{Results:-}

\section{Respondent Characteristics:-}

Table 4.1. The distribution frequency of respondent characteristic of hypertensive patients both intervention and control group.

\begin{tabular}{|c|c|c|c|c|}
\hline \multirow[t]{2}{*}{ Variable } & \multicolumn{2}{|c|}{ Intervention Group } & \multicolumn{2}{|c|}{ Control Group } \\
\hline & Frekuensi & $\%$ & Frekuensi & $\%$. \\
\hline 1. Age & & & & \\
\hline a. Adult (25-54) у.о. & 16 & 61,5 & 15 & 57,7 \\
\hline b. elderly (55-65) у.о. & 10 & 38,5 & 11 & 42,3 \\
\hline 2. Gender & & & & \\
\hline a. Male & 3 & 11,5 & 3 & 11,5 \\
\hline b. Female & 23 & 88,5 & 26 & 88,5 \\
\hline 3. Employment & & & & \\
\hline a. Work & 6 & 23,1 & 9 & 34,6 \\
\hline b. Workless & 20 & 76,9 & 17 & 65,4 \\
\hline 4. Treatment & & & & \\
\hline a. Regular & 22 & 84,6 & 23 & 88,5 \\
\hline b. Irregular & 4 & 15,4 & 3 & 11,5 \\
\hline 5. Exercise & & & & \\
\hline
\end{tabular}




\begin{tabular}{|l|c|c|c|c|}
\hline a. Yes & 7 & 26,9 & 9 & 34,6 \\
\hline b. No & 19 & 73,1 & 17 & 65,4 \\
\hline 6. Hypertension diet & & & & \\
\hline a. Regular & 4 & 15,4 & 6 & 23,1 \\
\hline b. Irregular & 22 & 84,6 & 20 & 76,9 \\
\hline
\end{tabular}

Based on the table it can be seen that the adult respondents more than elderly, both intervention (61.5\%) and control group $(57,7)$. Based on gender, female more than male, both intervention (88,5\%) and control group (88,5\%). Based on employment status, respondents who workless more than respondents who worked, in intervention group (76.9\%) and control group $(65.4 \%)$. Based on the treatment status of hypertension, most have been regularly treated, both intervention (84.6\%) and control group (88.5\%). Likewise diet high in salt or hypertension diet, more of them who do hypertensive diet but irregular, both the intervention $(84,6 \%)$ and control group $(76,9 \%)$. While in exercise, respondents who do not exercise more than those who exercise, both in the intervention (73.1) and control groups (65.4).

Star Point:-

Table 4.2:- The different mean diastolic BP before Hypno-EFT therapy day 1 between intervention and control group.

\begin{tabular}{|c|c|c|c|}
\hline Variable & Mean BP & SD & -value \\
\cline { 1 - 3 } Diastolic BP intervention group & $100,58 \mathrm{mmHg}$ & 8,524 & \multirow{2}{*}{0,734} \\
\hline Diastolic BP control group & $101,35 \mathrm{mmHg}$ & 7,689 & \multirow{2}{*}{} \\
\cline { 1 - 3 }
\end{tabular}

T-test data analysis obtained value of $\rho=0,720$. This showed that value of $\rho>0.05$ means there is no significant difference in mean systolic blood pressure between the intervention group and the control group at the beginning of therapy. The results of the test can be concluded that the intervention group and the control group have relative similar value star point of blood pressure.

\section{Univariate Analysis:-}

Diastolic blood pressure before and after Hypno-EFT therapy of intervention group and control group.

Chart 4.1:- Mean diastolic BP before and after Hypno-EFT therapy of intervention group and control group.

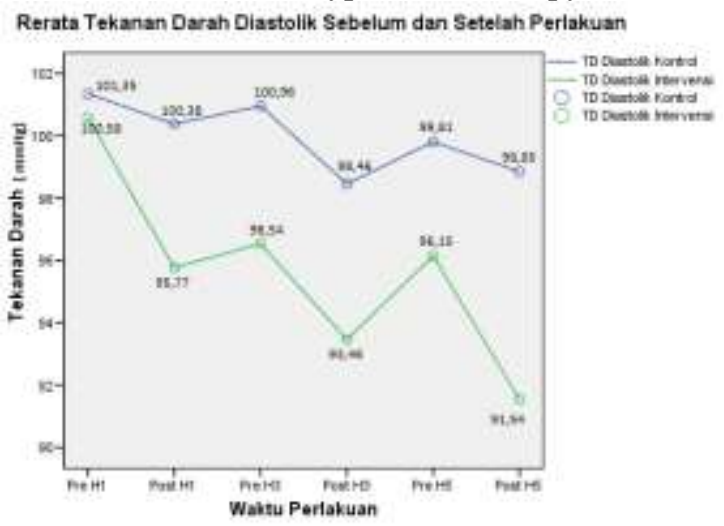

In intervention group after first day Hypno-EFT therapy there was decrease in mean systolic blood pressure of 7.5 $\mathrm{mmHg}$. But on the second day before therapy, the mean systolic blood pressure occurred slightly increased. Although the mean systolic blood pressure fluctuates at the beginning of therapy, but overall at the end of therapy there is a decrease in systolic blood pressure of $18.65 \mathrm{mmHg}$. While in the control group, was not given Hypno-EFT therapy but given an explanation about the management of hypertension in the family. During the three times visits the development of systolic blood pressure in control group slightly decreased of $5.58 \mathrm{mmHg}$.

Systolic blood pressure before and after Hypno-EFT Therapy of intervention group and control group. 
Chart 4.2:- Mean systolic blood pressure before and after Hypno-EFT therapy of intervention group and control group.

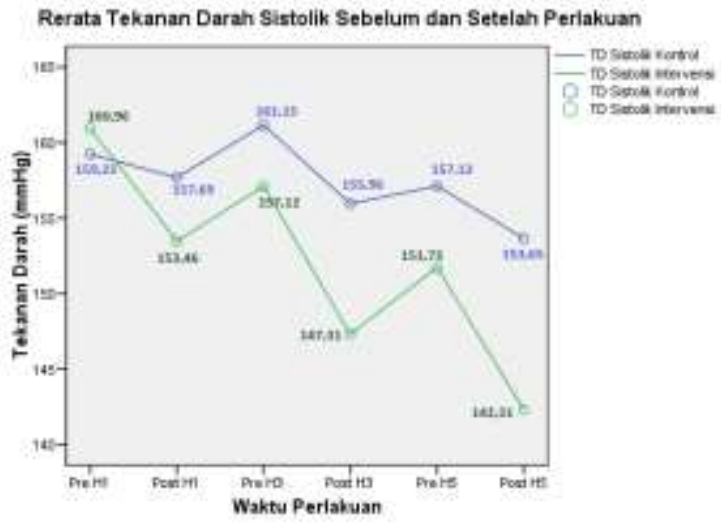

\section{Bivariate Analysis:-}

Mean difference of diastolic blood pressure after day $5^{\text {th }}$ Hypno-EFT therapy between intervention group and control group.

Table 4.4:- Mean difference of diastolic blood pressure after day 5th Hypno-EFT therapy between intervention group and control group

\begin{tabular}{|c|c|c|c|c|}
\hline Variable & Mean Blood Pressure & SD & $95 \%$ CI & $\rho$-value \\
\hline $\begin{array}{c}\text { Diastolic blood pressure of } \\
\text { intervention group }\end{array}$ & $91,54 \mathrm{mmHg}$ & 6,288 & \multirow{2}{*}{$3,445-11,170$} & 0,001 \\
\cline { 1 - 2 } $\begin{array}{c}\text { Diastolic blood pressure of control } \\
\text { group }\end{array}$ & $98,85 \mathrm{mmHg}$ & 7,524 & & \\
\hline
\end{tabular}

Result of data analysis obtained mean diastolic blood pressure after the last therapy in intervention group has difference $9.04 \mathrm{mmHG}$, while in control group $2.5 \mathrm{mmHg}$. Intervention group has $6.54 \mathrm{mmHg}$ higher difference number than control group. Based on result of t-test (non-paired) data analysis obtained significant value of $(\rho)=$ $0,001(\rho>0,05)$, means $\mathrm{H}_{0}$ rejected or it means there is the difference mean of diastolic blood pressure between intervention group and control group after Hypno-EFT therapy.

The Difference mean diastolic blood pressure day $1^{\text {st }}$ before intervention and day $5^{\text {th }}$ after intervention Hypno-EFT.

Table 4.6:- The Difference mean diastolic blood pressure day 1st before intervention and day 5 th after intervention Hypno-EFT.

\begin{tabular}{|c|c|c|c|c|}
\hline Intervention & Mean Blood Pressure & SD & 95\% CI & $\rho$-value \\
\hline Day 1 & $160,96 \mathrm{mmHg}$ & 18,440 & $13,755-23,553$ & 0,001 \\
\hline Day $5^{\text {th }}$ & $142,31 \mathrm{mmHg}$ & 16,385 & & \\
\hline
\end{tabular}

Result of data analysis obtained mean systolic of intervention group was decrease $18.65 \mathrm{mmHg}$ after given HypnoEFT therapy on day $5^{\text {th }}\left(3^{\text {rd }}\right.$ intervention of Hypno-EFT therapy). Based on paired-t test data analysis obtained significant value of $\rho=0,001(\rho<0,05)$, means $\mathrm{H}_{0}$ rejected or it means there is the difference mean systolic blood pressure of intervention group before and after given Hypno-EFT therapy.

\section{Discussion:-}

Result of this research showed that there is decrease of blood pressure both of systolic and diastolic in hypertensive patients after given 3 times intervention used Hypno-EFT therapy. All therapy was given at patient's house and the patients was teach to do Hypno-EFT therapy daily and independently. Mean of blood pressure decreased after given the therapy, but the examination before the therapy on the next day the blood pressure returns to increase. Based on statistics analysis there is significant difference mean blood pressure both of systolic and diastolic after Hypno-EFT therapy between intervention group and control group. Many potential factors that contribute in the formation of hypertension; these factors are increased activity of the sympathetic nervous system; increased response to psychosocial stress; excessive production of hormones that hold sodium and vasoconstrictors; excessive sodium (salt) intake; inadequate intake of potassium and calcium, increased secretion of renin resulting in increased 
production of angiotensin II and aldosterone; vasodilator deficiencies such as prostacyclin, nitric oxide (NO), and natriuretic peptides; changes in expression of the kallikrein-kinin system affecting vascular tone and salt handling by the kidneys; abnormalities of blood vessel resistance, including disorders of small blood vessels in the kidneys; diabetes mellitus; insulin resistance; obesity; increased activity of vascular growth factors; changes in adrenergic receptors that affect heart rate, inotropic characteristics of the heart, and vascular tone; changes in ion transport in cells (Department of Health, 2006).

Various factors such as anxiety and fear can affect the vascular response to vasoconstrictor stimuli. Hypertensive patients are very sensitive to norepinephrine, although it is not known exactly why it can happen (Brunner \& Suddarth's, 2013). Hypno-EFT is a therapy that combines the body's energy system with Hypnosis therapy that is used as one of therapy techniques to resolve the emotional and physical problems by doing a light tapping on the nerve point (meridian body). Hypnosis therapy used in the form of Hypnosis suggestion is affirmed with the patient during therapy (Gunawan, 2012).

Hypno-EFT is a short and effective method to reduce the disruption that associated with emotional memories that may underlie the physical symptoms and increase blood pressure. Studies have illustrated that EFT demonstrates a fast, effective, cost-effective, and easy-to-teach, how to deal with disorders such as anxiety, depression, and posttraumatic stress, as well as physical symptoms such as cravings and pains (Church and Brooks, 2010). These conditions if it occurs in patients with hypertension, would be more at risk of an increase in blood pressure that will threat the patient.

Hypertension patients who master in Hypno-EFT therapy, can perform independent therapy every day, especially when they faced with stressors that potentially cause stress both physically and emotionally. Nurses can teach Hypno-EFT therapy to hypertensive patients as one form of nursing intervention so that hypertensive patients able to perform Hypno-EFT independently. Nurse is one of health professions who caring patients with a holistic approach. Complementary therapies such as hypnosis and EFT are considered holistic approaches because they seek to heal patients by looking at the various angles and various aspects of the patient's life.

\section{References:-}

1. Bahtiar, Y., Hidayat, U.A., dan Hidayat, A.A.S., 2013. Hypnoterapi Membantu Menurunkan Stres Fisik dan Psikososial Pasien Hipertensi di Wilayah Dinas Kesehatan Kota Tasikmalaya. Majalah Buletin Media Informasi Poltekkes Kemenkes Tasikmalaya. Ed.1-2013: 130 - 139. ISSN: 2086 - 3292.

2. Budi, P.P., \& Rizali, E., (2010). Cara Cepat Menggusasi Hypno Healing. Yogyakarta: Ieutika

3. Brunner \& Suddarth's.,(2013). Keperawatan Medikal Bedah. Jakarta: EGC.

4. Charlie, L. (2011). Mengendalikan Penyakit Kardiovaskuler. Bandung: TriExs Media.

5. Church, D. and Brooks, A.J. (2010). The effect of a brief EFT self-intervention on anxiety, depression, pain, and cravings in health care workers. Integrative Medicine. P.40-43, Vol. 9, No. 5, Oct/Nov 2010. Diunduh dari http://search.ebscohost.com pada tanggal 29 Oktober 2016.

6. __ (2010). Application of emotional freedom techniques, Case studies. Integrative Medicine. P.36-38, Vol. 9, No. 5, Oct/Nov 2010. Diunduh dari http://search.ebscohost.com pada tanggal 29 Oktober 2016.

7. Dahlan, M.S., (2006). Besar sampel dalam penelitian kedokteran dan kesehatan. Jakarta: PT. Arkans.

8. _ (2009). Statistik untuk Kedokteran Kesehatan. Jakarta: Salemba Medika.

9. Dawson, Garret \& Audrey. (2012) The Effect of Emotional Freedom Techniques on Stress Biochemistry: A Randomized Controlled Trial: The Journal of Nervous and Mental Disease October 2012. Vol. 200 - Issue 10: p 891-896.

10. Depkes., (2008). Laporan Riskesdas Jawa Barat Tahun 2007. Jakarta: Depkes. RI.

11. _ (2006). Pharmaceutical care untuk penyakit hipertensi. Jakarta: Ditjen Bina Kefarmasian dan Alat Kesehatan Depkes RI.

12. Gunawan A.W., (2009). Quantum life transformation. Jakarta: PT Gramedia Pustaka Utama.

13. __ (2012). The miracle of mindbody medicine. How to use your mind for better health. Jakarta: PT Gramedia Pustaka Utama.

14. Jaret P., (2008). Ills \& Condition stress and pulmonary hypertension. Diunduh tanggal 20 April 2012 dari http://healthresources.caremark.com

15. Lin, G.H., at. all., (2016). Effectiveness of acupressure on the taichong acupoint in lowering blood pressure in patients with hypertension: a randomized clinical trial. Evidence-Based Complementary and Alternative 
Medicine. Volume 2016, Article ID 1549658, 9 pages: Hindawi Publishing Corporation. Diunduh dari http://search.ebscohost.com pada tanggal 29 Oktober 2016.

16. Majid, (2015). Emotional Freedom Technique. Diunduh pada tanggal 25 Januari 2016 dari http://www.hypnosis45.com

17. McKenzie, Pinger, \& Kotecki, (2007). Kesehatan Masyarakat Suatu Pengantar. Edisi 4.Alih bahasa; Utami A., dkk. Jakarta: EGC.

18. Rahajeng, E. (2009). Masalah Hipertensi di Indonesia. Diunduh tanggal 10 Maret 2012, dari http://digilib.litbang.depkes.go.id

19. Ramadhan, A.J. (2010). Mencermati Berbagai Gangguan pada Darah dan Pembuluh Darah. Jogyakarta: Diva press.

20. Santoso, D., (2010). Membonsai Hipertensi. Surabaya: Jaring pena.

21. Saputra, A., (2011). EFT-Emotional Freedom Technique. Yogyakarta: Genius Publisher.

22. Shestopal, I., (2014). Hypnotherapy for anxiety in private practice: SCL-90 results and case description. Contemporary hypnosis and intecrative therapy. 30(2), P: 93-101. British Society of Clinical and Academic Hypnosis, Crown House Publishing Ltd. Diunduh dari http://search.ebscohost.com pada tanggal 29 Oktober 2016.

23. Smeltzer, S.C., Bare., B.G., Hinkle, J.L. \& Cheever, K.H., (2008). Textbook of Medical-Surgical Nursing. Eleventh edition. Brunner, \& Suddarth's. Philadhelpia Lippincott Williams \& Wilkins, a Wolter Kluwer bussiness.

24. Susalit, E., Kapojos, EJ., \& Lubis, HR., (2003). Hipertensi Primer, dalam Suyono, S. (Eds). Ilmu Penyakit Dalam. Jakarta: Balai penerbit FKUI.

25. Susilawati, D. (2015). Hipertensi masih jadi masalah besar di Indonesia. Diunduh tgl. 20 Juni 2016 dari http://gayahidup.republika.co.id

26. Suwandi, A.,(2010). Turbo Hypnotis. Jakarta: PT Gramedia Pustaka Utama Kompas Gramedia Building.

27. Tagor, GM. (2002). Buku Ajar Kardiologi, Hipertensi Esensial. Jakarta: Balai Penerbit Fakultas Kedokteran Universitas Indonesia

28. Varvogli, L. and Darviri C., (2011). Stress Management Techniques: evidence-based procedures that reduce stress and promote health. P: 74-89, Health Science Journal, Volume 5, Issue 2. Diunduh dari http://search.ebscohost.com pada tanggal 29 Oktober 2016.

29. Yugiantoro, M. (2007) Hipertensi Esensial, dalam Sudoyo, AR. (Eds), Ilmu Penyakit Dalam. (pp. 599 - 603). Jakarta: Pusat penerbit IPD FKUI.

30. Zahourek, R. (2014). Book review. P.23, American Holistic Nurses Association: Diunduh dari http://search.ebscohost.com pada tanggal 29 Oktober 2016.

31. Zainuddin, A.F., 2014. Spiritual emotional freedom technique, SEFT for healing + success + happiness + greatness. Jakarta: Afzan publishng. 